Garon JM, Ziff ED. The Work Made for Hire Doctrine

Revisited: Startup and Technology Employees and the Use of Contracts in a Hiring Relationship. Minnesota Journal of Law, Science \& Technology. 2011;12(2):489-527.

\title{
The Work Made for Hire Doctrine Revisited: Startup and Technology Employees and the Use of Contracts in a Hiring Relationship
}

\section{Jon M. Garon* \& Elaine D. Ziff**}

\section{INTRODUCTION}

Copyright law assumes that the author of a work is the copyright owner. For novelists, painters, and composers, this assumption works quite well. However, the economic realities are somewhat different for software companies, motion picture makers, and the creators of technical journals or product manuals. For modern industry, it is less likely that a work will be created by an individual author and more likely that a work will be developed by a team of specialists in the scope of their professional endeavors. Corporate employees may be located across the globe or in their own homes, creating interrelated components of a single copyrighted work. Business arrangements for copyright must take these conditions into account.

A "work made for hire" is a copyrighted work as to which the employer or other person for whom the work was prepared

(C) 2011 Jon M. Garon \& Elaine D. Ziff.

* Professor of Law, Hamline University School of Law. An earlier version of this paper was produced for the American Bar Association, Business Law Section, Cyberspace Law Committee, 2011 Cyberspace Law Institute and incorporates small excerpts from JON M. GARON, OWN IT, THE LAW \& Business Guide to LAUnChing a New Business through InNovation, EXCLUSIVITY AND RELEVANCE (2007).

** Counsel, Intellectual Property and Technology Group, Skadden, Arps, Slate, Meagher \& Flom, LLP. The views expressed in this article do not necessarily represent the views of Skadden Arps or any one or more of its clients. 
[Vol. 12:2

is considered the author for purposes of the Copyright Act and-unless the parties have expressly agreed otherwise in a written instrument signed by them-owns all of the rights comprised in the copyright. ${ }^{1}$ Designation as a work for hire affects the copyright in four primary ways: ownership, term, moral rights, and termination rights. If a copyrighted work is a work for hire, then the initial ownership vests in the employer, rather than the employee or contractor, and that individual enjoys none of the legal or beneficial attributes of authorship. ${ }^{2}$

Current U.S. copyright law grants protection for the lifespan of the author plus seventy years to allow the copyright to benefit at least the author's first-generation heirs. ${ }^{3}$ Such a measurement is inappropriate for a corporate author. Thus, a work for hire has a somewhat arbitrary copyright term of "95 years from the year of its first publication, or a term of 120 years from the year of its creation, whichever expires first." 4 This remains true even if the employer happens to be an individual with a measurable lifespan. ${ }^{5}$

The Copyright Act also explicitly specifies that a work created as a work for hire cannot have protections under the Visual Artists Rights Act, the limited moral rights protections under U.S. copyright law. ${ }^{6}$ As a result, a work of art such as an oil painting, sculpture, or façade that is created as a work for hire will not have any of the protections afforded an artist under that Act to protect his or her right to claim authorship of the work and to prevent the mutilation or destruction of the work. ${ }^{7}$

Perhaps, most significantly, the statutory protection for authors to terminate grants of copyright, whether by

1. 17 U.S.C. $§ 201(b)$ (2006). These rights are: (1) the rights to reproduce the copyrighted work, (2) prepare derivative works of it, (3) distribute copies to the public by sale or other transfer of ownership or by rental, lease or lending, (4) perform and/or display the work publicly, (5) or, in the case of sound recordings, perform the work publicly by means of a digital audio transmission. Id. $§ 106$.

2. Id. $\S 201(\mathrm{~b})$.

3. Id. § 302(a) (applying to works created on or after January 1, 1978).

4. Id. $\S 302(\mathrm{c})$.

5. See id.

6. Id. $\S \S 101,106 \mathrm{~A}$. The definition of "work of visual art" expressly excludes any work made for hire. $I d$.

7. Id.; See e.g., Pollara v. Seymour, 344 F.3d 265 (2d Cir. 2003); Carter v. Helmsley-Spear, Inc., 852 F. Supp. 228 (S.D.N.Y. 1994). 
assignment or license, does not apply to works for hire. ${ }^{8} \mathrm{~A}$ copyright has historically been treated as having two separate grant terms for most authors-an initial term and a renewal term. ${ }^{9}$ Although this two-term structure was dropped in the current 1976 Copyright Act, one key aspect of this model was retained: an author can terminate an assignee's or licensee's right to the renewal term of works copyrighted prior to the 1976 Copyright Act ${ }^{10}$ or can terminate any license or transfer of a copyright made after January 1, 1978 (the effective date of the 1976 Copyright Act) between thirty-five and fourty years after the grant was made. ${ }^{11}$

Since the copyright in a work for hire initially vests in the employer rather than the employee, the law does not treat the arrangement as a transfer of the copyright and, therefore, does not provide the author the right to terminate the grant. ${ }^{12}$ The law also precludes the employer from using the Copyright Act termination provisions to terminate its own grants to third parties. ${ }^{13}$ The elimination of the termination provisions provides greater confidence that works created in the employment environment will not be later recaptured through

8. 17 U.S.C. $\S \S 203,304(c)-(d)$.

9. See id. §304(c).

10. Id.

11. Id. § 203(a).

(3) Termination of the grant may be effected at any time during a period of five years beginning at the end of thirty-five years from the date of execution of the grant; or, if the grant covers the right of publication of the work, the period begins at the end of thirty-five years from the date of publication of the work under the grant or at the end of forty years from the date of execution of the grant, whichever term ends earlier.

(4) The termination shall be effected by serving an advance notice in writing, signed by the number and proportion of owners of termination interests required under clauses (1) and (2) of this subsection, or by their duly authorized agents, upon the grantee or the grantee's successor in title.

$I d$.

12. Id. $\S \S 203(\mathrm{a}), 304(\mathrm{c})-(\mathrm{d})$. The estate of comic book artist, Jack Kirby, who is recognized for superhero characters like Iron Man and Spiderman, recently served fourty-five notices of copyright termination on Marvel Entertainment. In response, Marvel filed a lawsuit in New York Federal District Court seeking a declaratory judgment that various comic book creations were works for hire. The case is potentially worth billions of dollars. Erline Aguiluz, Jack Kirby's Estate Battles Marvel Over Copyright Termination, N.Y. EsTATE PlanNING NEWS (Dec. 8, 2010, 8:59 AM), http://newyorkestateplanningnews.com/2010/12/jack-kirbys-estate-battlesmarvel-over-copyright-termination.html.

13. 17 U.S.C. $\S \S 203(a), 304(c)-(d)$. 
terminations.

Although not as long as ninety-five years, the copyright term of a work for hire, an initial grant of rights for thirty-five years, seems quite long for corporate publishers. Few copyrighted works of a business nature have shelf lives measured in decades. Why then, is the longer term obtained with work for hire important? The difference between a grant of copyright from the author, and an automatic transfer of copyright under the work for hire doctrine, might have longterm consequences.

For companies that rely on older works as the basis of newer works, such as publishers of software, reference works, or other works that change incrementally, the ability of authors to terminate grants could become very disruptive. Software code or sections of updated works would need to be stripped out from versions of editions of the work that are published following the termination. The consequence of this is not easy to predict. Under the Copyright Act, the existing work can be utilized but new updates would not be authorized. ${ }^{14}$

Treatise author David Nimmer illustrates this consequence using motion picture production as the example:

[A] grant of motion-picture rights in a novel will authorize the preparation of a motion picture based upon the novel; even after the statutory termination of such a grant, the grantee will continue to have the right to "utilize" the film made pursuant thereto. In such circumstances, a grantee would not have the right after termination to prepare a new motion picture based upon the same novel. ${ }^{15}$

By the same logic, a software product may be sold following the termination of an assignment or license to use some or all of the code in the product. However, new derivative worksperhaps including even minor updates-may no longer be authorized. As a result, there can be significant impacts if a work is characterized as an assignment or license of rights instead of being a work for hire.

14. Id. $\S \S 203(\mathrm{~b})(1), 304(\mathrm{c})(6)(\mathrm{A})$.

A derivative work prepared under authority of the grant before its termination may continue to be utilized under the terms of the grant after its termination, but this privilege does not extend to the preparation after the termination of other derivative works based upon the copyrighted work covered by the terminated grant.

Id. $\S 203(\mathrm{~b})(1)$

15. 3 DAVID NIMMER, NIMMER ON COPYRIGHT $§ 11.02$ [C] (2010) (footnotes omitted). 
Where a person creates a wholly-owned business entity, such as a personal corporation or LLC, the transfer of rights to that entity on a work for hire basis will result in the same changes to the author's rights in the copyrighted work as if the work was created as a work for hire for an unrelated employer. As a result, the copyright term, the author's termination rights, and moral rights are affected, along with the identity of the work's author. A person who forms a personal corporation may wish to include a written agreement between such person and the entity, specifying that copyrighted works shall not be treated as works for hire. ${ }^{16}$ This may, however, affect the commercial desirability of the entity's work product to third parties.

\section{WHEN IS A WORK MADE FOR HIRE?}

United States copyright law provides two very distinct categories of work for hire. The first category regulates traditional employment or agency relationships. "A "work made for hire" is . . . a work prepared by an employee within the scope of his or her employment . .."17 The second category of work for hire deals with specially commissioned works. ${ }^{18}$ To be characterized as a work for hire under this category, the work must fall into one or more of the nine statutorily enumerated categories and the for-hire relationship must be evidenced by a writing signed by both parties. ${ }^{19}$ The application of the two rules does not overlap and each should be analyzed separately.

16. See 17 U.S.C. $§ 201(b)$.

17. Id. $\S 101$.

18. Id.

19. Id. § 101. The statute defines a "work make for hire" as:

a work specially ordered or commissioned for use as a contribution to a collective work, as a part of a motion picture or other audiovisual work, as a translation, as a supplementary work, as a compilation, as an instructional text, as a test, as answer material for a test, or as an atlas, if the parties expressly agree in a written instrument signed by them that the work shall be considered a work made for hire. For the purpose of the foregoing sentence, a 'supplementary work' is a work prepared for publication as a secondary adjunct to a work by another author for the purpose of introducing, concluding, illustrating, explaining, revising, commenting upon, or assisting in the use of the other work, such as forewords, afterwords, pictorial illustrations, maps, charts, tables, editorial notes, musical arrangements, answer material for tests, bibliographies, appendixes, and indexes, and an 'instructional text' is a literary, pictorial, or graphic work prepared for publication and with the purpose of use in systematic instructional activities. 
For a work to be considered a work for hire of an entity, the entity must be formed at the time the work is created. ${ }^{20}$

\section{A. Traditional Employees UNDER WORK FOR HiRE}

Under a regular employer/employee relationship, the copyright in a work vests in the employer when the copyrighted work is "prepared by an employee within the scope of his or her employment." 21 The law of agency applies to determine when a person is considered an employee. ${ }^{22}$ As the Supreme Court explained in Committee for Creative Non-Violence v. Reid, "[t]o determine whether a work is for hire under the Act, a court first should ascertain, using principles of general common law of agency, whether the work was prepared by an employee or an independent contractor. After making this determination, the court can apply the appropriate subsection of $\S 101$. " 23

The Supreme Court, in Committee for Creative NonViolence $v$. Reid, provided a non-exclusive list of factors determining common law agency in the work for hire context, often referred to as the "Reid factors." 24 Interpreting these

20. Woods v. Resnick, 725 F. Supp. 2d 809, 825 (W.D. Wis. 2010); see also 1 DAVID Nimmer, Nimmer ON Copyright, § 5.03[B] (2010); Billy-Bob Teeth, Inc. v. Novelty, Inc., 329 F.3d 586, 591 (7th Cir. 2003) (corporation could not establish ownership under work for hire theory because it did not exist when author created work). But see Jules Jordan Video, Inc. v. 144942 Canada Inc., 617 F.3d 1146, 1156-57 (9th Cir. 2010) (finding harmless error the failure for a one-person company to properly distinguish copyright ownership as vesting in the company or its owner); Logicom Inclusive, Inc. v. W.P. Stewart \& Co., 72 U.S.P.Q.2d 1632, 1639 (S.D.N.Y. 2004) ("[T]he annulment of Logicom's dissolution in May of 2003 should have retroactive effect, so that Logicom was a legal entity capable of authoring and owning copyright of the two computer programs at issue.").

21. 17 U.S.C. $\S 101$.

22. Cmty. for Creative Non-Violence v. Reid, 490 U.S. 730, 750-51 (1989).

23. Id.

24. The list of factors considered by the Supreme Court include:

In determining whether a hired party is an employee under the general common law of agency, we consider the hiring party's right to control the manner and means by which the product is accomplished. Among the other factors relevant to this inquiry are the skill required; the source of the instrumentalities and tools; the location of the work; the duration of the relationship between the parties; whether the hiring party has the right to assign additional projects to the hired party; the extent of the hired party's discretion over when and how long to work; the method of payment; the hired party's role in hiring and paying assistants; whether the work is part of the regular business of the hiring party; whether the hiring party is in 
common law agency factors, the Second Circuit has suggested a narrower group of factors:

$[T]$ here are some factors that will be significant in virtually every situation. These include: (1) the hiring party's right to control the manner and means of creation; (2) the skill required; (3) the provision of employee benefits; (4) the tax treatment of the hired party; and (5) whether the hiring party has the right to assign additional projects to the hired party. These factors will almost always be relevant and should be given more weight in the analysis, because they will usually be highly probative of the true nature of the employment relationship. ${ }^{25}$

Similar factors have been applied in determining whether an employment relationship exists for other purposes, such as whether a sales representative is an employee for purposes of bringing a Title VII sexual harassment claim against the hiring party 26 or whether a medical doctor is an employee of his practice group for purposes of taking a tax deduction for a malpractice settlement 27

Of the Reid factors, the Second Circuit stated in 1992 that employee benefits and tax treatment carried the greatest weight. ${ }^{28}$ This was because these factors were viewed as a "virtual admission" by the hiring party as to the nature of the relationship and because it would be inequitable to allow an employer to treat the hired party as a contractor for benefits and payroll taxes purposes while treating him or her as an employee for copyright purposes. 29 The Eighth Circuit reiterated this statement in 1999 in holding that a programmer was an independent contractor largely because the hiring party failed to extend him employee benefits or pay social security taxes, even though other factors pointed to an employment

business ... the provision of employee benefits; and the tax treatment

of the hired party. . . . No one of these factors is determinative.

Id. at 751-52 (internal citations omitted).

25. Aymes v. Bonelli, 980 F.2d 857, 861 (2d Cir. 1992).

26. Russell v. BSN Med., Inc., 721 F. Supp. 2d 465, 472 (W.D.N.C. 2010) (citing the Reid factors in finding that a sales representative was an employee for purposes of a Title VII sexual harassment claim).

27. Maimon v. Comm'r, T.C. Summ. Op. 2009-53, 55 (2009). Guidelines for determining the existence of employment relationship for tax purposes are based on common law definition of an employee. Id.

28. Aymes, 980 F.2d at 863 ("The importance of these two factors is underscored by the fact that every case since Reid that has applied the test has found the hired party to be an independent contractor where the hiring party failed to extend benefits or pay social security taxes.").

29. $I d$. 
relationship. ${ }^{30}$

The Second Circuit has since moderated its position with respect to Title VII cases, stating that "the 'greatest emphasis' should be placed on the first factor-that is, on the extent to which the hiring party controls the 'manner and means' by which the worker completes his or her assigned tasks." 31 It is too easy for the parties to manipulate workers compensation arrangements thereby denying a worker the benefit of the antidiscrimination laws. ${ }^{32}$ However, the court, in dicta, noted that the "special consideration" accorded to benefits and tax treatment may still make sense in the copyright work for hire context because the copyright statute allows workers and employers to allocate intellectual property rights by contract. ${ }^{33}$

A recent traditional application of the Reid work for hire factors to software created by a consultant was exemplified by Numbers Licensing, LLC v. bVisual USA, Inc. ${ }^{34}$ The case for the programmer, Rance Renfroe, being an independent contractor was made easier by the fact that he worked through a personal corporation he formed with his wife, Numbers Licensing, LLC (Numbers). ${ }^{35}$ In particular, Renfroe was found not an employee of bVisual, a software development company, because: (1) Numbers sent bVisual weekly invoices for Renfroe's work; (2) Numbers was responsible for Renfroe's payroll obligations, tax obligations, and employee benefits; (3) Numbers supplied much of the equipment used, including computers and other standard development tools; (4) although one of the two founders of bVisual was heavily involved in some aspects of the codes' creation, he was not capable of detailed code review; (5) Renfroe's services were sought for a specific purpose-specialized programming knowledge-and bVisual had no right to assign additional projects to Renfroe, as it

30. Kirk v. Harter, 188 F.3d 1005, 1008-09 (8th Cir. 1999) (noting other factors present including: that the programmer traveled with the company president to clients, attended trade shows wearing a company uniform, his hours were directed by the company, the parties had a six-year relationship, and the programmer spent a significant amount of time working at the company's offices).

31. Eisenberg v. Advance Relocation \& Storage, Inc., 237 F.3d 111, 114 (2d Cir. 2000).

32. Id. at $116,117-118$.

33. Id. at 117 .

34. 643 F. Supp. 2d 1245, 1252 (E.D. Wash. 2009).

35. Id. at 1251 . 
would a regular salaried employee; (6) Renfroe wrote the code primarily at Numbers' offices at his own schedule with discretion as to how he performed his work; (7) there were instances where Renfroe denied being an employee, for example, crossing out "employee" and writing "contractor" on his employee handbook; and (8) communications between Renfroe and the Company, such as those contained in Company's Confidentiality Agreement Renfroe signed, had a "we" vs. "you" mentality. ${ }^{36}$

\section{TECHNOLOGY STARTUPS}

Where technology startups are concerned, some recent decisions have taken a more flexible approach to applying the Reid factors to accommodate less traditional arrangements. ${ }^{37}$ The tax and benefits treatment of the hired party did not control the outcome. ${ }^{38}$ As a result, whether a copyrighted work will be owned by the controlling party has become more unpredictable.

In particular, two recent cases, one which held for the employer and the other for the programmer, recognized the special circumstances that apply with respect to technology startups and software developers. ${ }^{39}$ The informality with which these types of companies typically operate as to record-keeping, the creative compensation arrangements utilized by new ventures, as well as the fact that programmers can readily work remotely with minimal direct oversight from nontechnical management, distinguishes technology startups in the work for hire area.

\section{A. JUSTMED V. BYCE}

In JustMed, Inc. v. Byce, the Ninth Circuit favored the employer over the programmer, finding that JustMed owned the code at issue as a work for hire, in large measure because it was a startup technology company. ${ }^{40}$ The Ninth Circuit

36. Id. at 1251. This factor is somewhat questionable as many standard form employee non-disclosure and invention assignment agreements use such terminology as a colloquial alternative to legalese like, "party of the first part" or "employer" and "employee."

37. See JustMed Inc. v. Byce, 600 F.3d 1118, 1126 (9th Cir. 2010); Woods v. Resnick, 725 F. Supp. 2d 809, 824 (W.D. Wis. 2010).

38. JustMed, 600 F.3d at 1128.

39. See id.; Woods, 725 F. Supp. 2d at 824.

40. JustMed, 600 F.3d at 1126. 
affirmed the United States District of Idaho's finding that the programmer, Michael Byce, was an employee, not an independent contractor of JustMed when he wrote the source code for an artificial larynx. ${ }^{41}$ As a result, the code was covered by the work for hire doctrine and JustMed was considered the copyright owner. ${ }^{42}$

The facts of JustMed evidence a typical startup company scenario: Michael Byce and Joel Just were brothers-in-law and together they hatched the idea for the product. ${ }^{43}$ They even got a patent as co-inventors for the hands-free aspect of the device. ${ }^{44}$ Byce ceased work on the project for several years after his wife died, but Just nonetheless offered Byce stock in JustMed and a position on JustMed's board. ${ }^{45}$ In the meantime, Just hired Jerome Leibler to develop a new hardware prototype and write source code. ${ }^{46}$ When Leibler moved to Kentucky, Byce stepped back into the company and took over the development of the source code and Leiblers' compensation package. ${ }^{47}$ Byce worked at home in Idaho (JustMed's headquarters was in Oregon) and discussed the source code with Just, but Just never personally edited the code. ${ }^{48}$ Until three months before the dispute, Byce was paid solely in stock, but he never actually received any share certificates; they accrued in a notebook maintained by Just. 49

Upon becoming aware of the disparity in share ownership between himself and Just and Leibler, Byce attempted to protect "his" intellectual property. ${ }^{50} \mathrm{He}$ changed the copyright notice on the software to reflect his own name, not JustMed's. ${ }^{51}$ Two days before Just was scheduled to meet with a prospective merger partner, Byce deleted the code from JustMed's computer, leaving JustMed with only an earlier version, which

41. Id. at 1128 .

42. $I d$.

43. JustMed, Inc. v. Byce, No. CV005-333-S-MHW, 2007 WL 2479887, at *2 (D. Idaho Aug. 29, 2007), aff'd in part, rev'd in part, 600 F.3d 1118 (9th Cir. 2010).

44. Id.

45. Id. at $* 2-* 3$.

46. Id. at *3.

47. Id. at *4.

48. Id. at *5.

49. Id. at * $3,{ }^{*} 6$.

50. Id. at $* 6$.

51. Id. at *5. 
did not run properly. 52 JustMed brought state law conversion claims, but to prevail, it was required to prove that it owned the code. ${ }^{53}$ In the absence of any written agreement, JustMed's ownership claim rested solely on the application of the work for hire doctrine. ${ }^{54}$

If Byce was an employee of JustMed, then the preparation of the code was within the scope of his employment. ${ }^{55}$ The argument turned on whether Byce was an employee or an independent contractor. ${ }^{56}$ Weighing in favor of Byce being an employee were the following factors:

- The duration of the relationship was indefinite/permanent and Byce did not have a defined end to his term. ${ }^{57}$

- Byce did other work for JustMed besides programming. He worked on the company's website, appeared at trade shows, and was a director. He had a business card that said "Director of Engineering." 58

- JustMed hired Byce to replace Leibler, an employee, and Byce inherited Leibler's compensation arrangements, namely a monthly salary paid in stock, so Byce's arrangements were like other JustMed employees. ${ }^{59}$

- Byce was paid monthly, not at the completion of his specific project. ${ }^{60}$

- Byce's work was integral to JustMed's primary business - the development and marketing of the device, which could not work without functioning software; the continuous updating of this software was too important to be left to an independent contractor. 61

Weighing in favor of Byce's treatment as an independent contractor were the following factors:

52. Id. at *7.

53. Id. at *1.

54. $I d$.

55. 17 U.S.C. $\S 101(2006)$.

56. JustMed, 2007 WL 2479887, at *1.

57. JustMed Inc. v. Byce, 600 F.3d 1118, 1126 (9th Cir. 2010).

58. JustMed, 2007 WL 2479887, at *5, *9).

59. JustMed, 600 F.3d at 1126-27.

60. Id. at 1127 .

61. Id. 
- Byce was not paid a cash salary or benefits and was never provided with actual share certificates. ${ }^{62}$

- Until right before the lawsuit, JustMed did not treat Byce as an employee for tax purposes ${ }^{63}$.

- Byce did not fill out employment forms. ${ }^{64}$

- Byce worked independently with little direct supervision from the company. ${ }^{65}$

The Court gave the financial factors the short shrift in light of JustMed's status as a startup company and because these factors did not bear directly on the substance of the employment relationship, namely the right to control. 66 Just testified that he did not think he had to comply with any employment reporting requirements because Byce was an "executive" and startup companies tend to pay employees in stock which is never reported as income because it has uncertain value. ${ }^{67}$ The court concluded that:

JustMed's treatment of Byce with regard to taxes, benefits, and employment forms is more likely attributable to the start-up nature of the business than to Byce's alleged status as an independent contractor. The indications are that other employees, for example Liebler, were treated similarly. Insofar as JustMed did not comply with federal and state employment or tax laws, we do not excuse its actions, but in this context the remedy for these failings lies not with denying the firm its intellectual property but with enforcing the relevant laws.

As a small start-up company, JustMed conducted its business more informally than an established enterprise might. This fact can make it more difficult to decide whether a hired party is an employee or an independent contractor, but it should not make the company more susceptible to losing control over software integral to its product. 68

The court also dismissed arguments that JustMed's lack of control over the manner and means by which Byce created the source code-facts that Reid found most critical 69 _required a finding that Byce was not an employee. ${ }^{70}$ True, Byce worked at

62. JustMed, 2007 WL 2479887 , at $* 3,{ }^{*} 6$.

63. Justmed, 600 F.3d at 1128.

64. Id.

65. See JustMed, 2007 WL 2479887, at *5.

66. JustMed, 600 F.3d at 1128.

67. Id. at $1121-22$.

68. Id. at 1128 .

69. Cmty. for Creative Non-Violence v. Reid, 490 U.S. 730, 750-51 (1989).

70. JustMed, 600 F.3d at 1127. 
home in another state, set his own hours, and had little direct supervision from JustMed. ${ }^{71}$ But the Court noted that these factors are not as important to a technology startup as to an established company, 72 nor are they as relevant in the software area. As an "inventive computer programmer," Byce was expected to work independently. ${ }^{73}$ "The business model and Byce's duties [did] not require that the project be completed in a particular manner or that Just continuously oversee Byce's work, so long as JustMed eventually found itself with a marketable product."74 Email and phone input were adequate. ${ }^{75}$ The court concluded:

The nature of the business and the work [meant] that Byce's ability to set his own hours and [work] from home are not particularly relevant. As a programmer, Byce ... [can] ply his craft at any time and from any place without any significant impairment to its quality or his ability to meet JustMed's needs. So although physical separation between the hiring party and the [employer] is often relevant to determining employment status, it is less germane in light of the kind of work Byce was doing. ${ }^{76}$

\section{B. WOODS V. RESNICK}

The case of Woods $v$. Resnick 77 followed on the heels of JustMed v. Byce, but came out the opposite way, favoring the programmer on somewhat similar facts. ${ }^{78}$ Adam Resnick and Erick Woods were equal partners in F\&I Source LLC, a software company that developed, maintained, and licensed a web-based software program used in the auto finance industry. ${ }^{79}$ After examining the work for hire factors, the court held that Woods, the partner who wrote the code, was not an employee of F\&I Source. 80 Thus, the absence of a signed agreement from Woods assigning the copyright to Resnick or to the company, along with a determination that joint ownership

71. Id. at 1122 .

72. Id. at 1127.

73. Id.

74. Id. In this regard, the Court noted that the RESTATEMENT (SECOND) OF AGENCY $\S 220$, cmt. e, (1958), explains that "[t]he custom of the community as to the control ordinarily exercised in a particular occupation is of importance." Id. at 1127 n.7.

75. Id. at 1127.

76. Id. at $1127-28$.

77. Woods v. Resnick, 725 F. Supp. 2d 809, 809 (W.D. Wis. 2010).

78. Id. at $813-16$.

79. Id. at 812 .

80. Id. at 824 . 
was not proven, prompted the court to hold that Woods was the program's sole author. ${ }^{81}$

The facts that led the court to find that Woods was not an employee of F\&I Source were as follows: (1) Resnick, a finance director for various car dealerships, came up with an idea for a customizable auto finance program;82 (2) he developed a working prototype consisting of spreadsheets, diagrams, and notes, but did not have programming expertise;83 (3) accordingly, the source code for the program was produced primarily, if not exclusively, by Woods, Resnick's high school friend;84 (4) Woods worked full-time out of his home on his own computer, borrowing some portions of the code from a project he had worked on previously; ${ }^{85}$ (5) Woods set his own hours and worked independently without oversight from Resnick, although the two would often exchange "task lists and ... emails identifying things that needed to be done to the system"; 86 (6) Woods received a monthly draw against future distributions of profits pursuant to a K-1 tax statement; 87 (7) other employees of F\&I Source, handling sales and marketing, received wages and W-2 statements from the company; 88 (8) Woods' home address was listed as the company's principal place of business. ${ }^{89}$

Woods had conceded he was not an independent contractor, leading Resnick to argue that he must be an employee. ${ }^{90}$ Woods countered that he was neither an independent contractor nor an employee; rather he was "a 50\% owner and member of F\&I Source, LLC." 91

The District Court for the Western District of Wisconsin adopted Wood's position. ${ }^{92}$ As a co-owner of the company, the Court stated that Woods did not have an agency relationship

\footnotetext{
81. Id. at 826 .

82. Id. at 813 .

83. Id.

84. Id. at 815 .

85. Id. at 814 .

86. Id. at 815 .

87. Id. at 814 .

88. See id.

89. Id. at 815 .

90. Id. at 824 .

91. Id.

92. Id.
} 
with the company. ${ }^{93}$ The Court reasoned further, "[u]nlike an employee or independent contractor, an owner has an inherent right to control the business. '[T] he attribute of co-ownership distinguishes a partnership from a mere agency relationship. . . . Ownership involves the power of ultimate control."”94

From this foundation of mutual ownership and control by the co-owners, the Court inferred that F\&I Source did not meet the control factors required by Reid:

As equal partners in the LLC, Woods and Resnick have equal voting rights. There is no operating agreement or deadlock-breaking agreement. As a result, unless both of them agree to a particular action, deadlock ensues. In other words, the company does not have the ability to compel either owner to take action. Under this scenario, there is no basis for finding that Woods was an employee under the control of F\&I Source. 95

Of course, the rationale of co-ownership would have been less compelling had the author owned less than fifty percent of the hiring party's equity.

Also supporting the Court's conclusion that Woods' code was not a work for hire was the fact that the LLC asserting ownership was not formed until after Woods had written the program and assembled a product that was ready for distribution to the public. ${ }^{96}$ The Court dismissed pre-formation activities as nothing "more than a working trade name that the parties were using while they developed their project." 97 Resnick failed to contend there had existed a general partnership prior to the formation of the LLC, despite the ongoing activities between the two parties. ${ }^{98}$ Given the Court's view of the Reid control factors, favoring Woods, a determination that the entity had existed as a general partnership would likely have had little effect on the outcome,

93. Id. But see WIS. STAT. § 183.0301(1)(a) (2009) ("Each member is an agent of the limited liability company, but not of the other members or any of them, for the purpose of its business."). The applicable Wisconsin statute stands at odds with the assertion of the Court. At the partnership stage, the result is the same. See WIS. STAT. § 178.06 (1) (2009) ("Every partner is an agent of the partnership for the purpose of its business . . ..").

94. Woods, 725 F. Supp. 2d at 824 (quoting REVISED UNIFORM PARTNERSHIP ACT $\S 202(\mathrm{a})$, cmt. (1997)).

95. Id. (citation omitted).

96. Id. at 825 .

97. Id.

98. Id. See WIS. STAT. § 178.03 (1) (2009) ("A partnership is an association of 2 or more persons to carry on as co-owners [sic] a business for profit."). 
but it would have at least precluded an independent basis for denying work for hire ownership. ${ }^{99}$

Moreover, the outcome would likely have been the same even if the Court had not focused on the novel basis of company co-ownership: Woods received no benefits, his compensation came from company profits, and Woods worked out of his house. ${ }^{100}$ Almost every Reid factor weighed in Woods' favor.

The Court, however, felt compelled to acknowledge the recent Ninth Circuit decision in JustMed $v$ Byce. It admitted that the JustMed case stands for the proposition that "some of the Reid factors tending to show that a party is an independent contractor-such as the hiring party's lack of day-to-day oversight over the other party and failure to pay employment benefits-have less weight given how technology start-ups operate."101 Nevertheless, the Court distinguished JustMed on its facts: in JustMed there was a corporation, not an LLC with two equal members, and Byce was "hired" by JustMed to replace an employee and was paid the same salary as that employee. 102

While the Woods decision emphasizes the control factors inherent in the jointly-owned LLC, the differing outcomes in JustMed and Woods may also be explained by reference to the equities. In JustMed, Byce attempted to derail the sale of the company and extract leverage with respect to his stock ownership by altering the copyright notice and deleting the code. ${ }^{103}$ The case arose as a conversion claim. ${ }^{104}$ In addition, the district court found that Byce was not a "credible witness" concerning his compensation. ${ }^{105}$ By contrast, in Woods the copyright notice always said "Erick Woods," the parties were seeking a declaratory judgment, and Resnick's testimony that he wrote some of the code was called into question. ${ }^{106}$

99. Cf. Jules Jordan Video, Inc. v. 144942 Canada Inc., 617 F.3d 1146, 1156-57 (9th Cir. 2010) (finding harmless error the failure for a one-person company to properly distinguish copyright ownership as vesting in the company or its owner).

100. Woods 725 F. Supp. 2d at 814-15.

101. Id. at 824 .

102. Id.at 824-25 (citations omitted).

103. JustMed Inc. v. Byce, 600 F.3d 1118, 1122 (9th Cir. 2010).

104. Id. at 1123 .

105. Id. at 1127.

106. Woods 725 F. Supp. 2d. at 812, 813, 815. 


\section{INTERPRETING WORK FOR HIRE CLAUSES}

Even where an employment relationship is unquestionable, copyright law and the work for hire doctrine can create ambiguity as to the vesting of copyrights in new materials. Thus, a written agreement may be used with employees to clarify what work is to be vested in the employer as a work for hire and what work is to be retained by the employee. ${ }^{107}$ The parties can agree whether a relationship is an employment relationship or modify the work for hire provision's requirement that a particular work is within the scope of employment. ${ }^{108}$ Yet, even a work prepared by an employee will not be regarded as a work for hire if it is not prepared in the "scope of employment."109 "Therefore, an agreement between an employer and employee whereby works prepared by the employee that are not prepared within the scope of employment are nevertheless deemed to be 'works made for hire,' will not in itself, convert such works into the 'for hire' category." 110

107. See id. at 813 (describing such an agreement).

108. Arguably two parties cannot claim an employment relationship where the common law agency factors clearly demonstrate that no such relationship would exist. This was the reason the music industry attempted to include sound recordings under the category of specially commissioned works, an amendment which was once incorporated as a technical correction to the Copyright Act, but then retroactively withdrawn. See 17 U.S.C. $§ 101$ (2006).

In determining whether any work is eligible to be considered a work made for hire under paragraph (2), neither the amendment contained in section 1011(d) of the Intellectual Property and Communications Omnibus Reform Act of 1999, as enacted by section 1000(a)(9) of Public Law 106-113, nor the deletion of the words added by that amendment-

(A) shall be considered or otherwise given any legal significance, or (B) shall be interpreted to indicate congressional approval or disapproval of, or acquiescence in, any judicial determination,

by the courts or the Copyright Office. Paragraph (2) shall be interpreted as if both section 2(a)(1) of the Work Made For Hire and Copyright Corrections Act of 2000 and section 1011(d) of the Intellectual Property and Communications Omnibus Reform Act of 1999, as enacted by section 1000(a)(9) of Public Law 106-113, were never enacted, and without regard to any inaction or awareness by the Congress at any time of any judicial determinations.

Id. So a copyright assignment clause which states that "the parties hereby recognize that Author hereunder is an employee for purposes of copyright but for no other purpose (including inter alia, tax and labor laws) ..." would likely be disregarded by the fact-finder if the remaining Reid factors dictated an independent contractor relationship. To do otherwise would circumvent the limitations on specially commissioned works embodied in the Copyright Act.

109. 5 DAVID NIMMER, NIMMER ON COPYRIGHT, § 5.03[B][1][b][ii] (2010).

110. Id. 


\section{A. MATTEL INC. V. MGA ENTERTAINMENT, INC.}

In the case of an express employment agreement, uncertainty can exist based on the interpretation of the contractual terms. In Mattel, Inc. v. MGA Entertainment, Inc., the Ninth Circuit addressed the impact of a written employment agreement used to augment the work for hire doctrine. ${ }^{111}$ The appeal focused on the written agreement between a Mattel employee, Carter Bryant, and Mattel.112 "Bryant worked in the 'Barbie Collectibles' department [of Mattel], where he designed fashion and hair styles for high-end Barbie dolls intended more for accumulation than for play." 113 During the time period that Bryant was employed at Mattel, he created sketches, a crude mock-up, and had the ideas for several doll names, all of which he pitched to Mattel's competitor, MGA.114 Bryant subsequently left Mattel for a consulting arrangement with MGA to work on the development of the Bratz line. ${ }^{115}$ A flurry of lawsuits by Mattel followed, asserting that it was the owner of the intellectual property rights in the Bratz dolls, including the doll names. ${ }^{116}$

Bryant's employment contract included the following somewhat standard language:

I agree to communicate to the Company as promptly and fully as practicable all inventions (as defined below) conceived or reduced to practice by me (alone or jointly by others) at any time during my employment by the Company. I hereby assign to the Company . . . all my right, title and interest in such inventions, and all my right, title and interest in any patents, copyrights, patent applications or copyright applications based thereon. ${ }^{117}$

The contract further specified that, "the term 'inventions' includes, but is not limited to, all discoveries, improvements, processes, developments, designs, know-how, data computer programs and formulae, whether patentable or unpatentable."118

111. Mattel, Inc. v. MGA Entm't, Inc., 616 F.3d 904, 912 (9th Cir. 2010).

112. Id. at 910 .

113. Id. at 907 .

114. Id.

115. Id.

116. Id. at 910 .

117. Id. at 909 (emphasis omitted).

118. Id. (citations omitted) (internal quotation marks omitted). 
The language of Bryant's employment contract did not expressly cover "ideas." 119 It did, however, apply to inventions "conceived as well as those reduced to practice," suggesting that the assignment governed works that were not yet fixed. ${ }^{20}$ The District Court for the Central District of California found the provisions of Bryant's employment contract covered ideas such as those involving the doll names "Bratz" and "Jade" as a matter of law. ${ }^{121}$ The Ninth Circuit held that this finding should have been submitted to the jury based on extrinsic evidence, including reference to other Mattel employee contracts that included "ideas," and the common perceptions in the design industry. ${ }^{122}$

Yet, even if Bryant's employment contract covered his ideas, other contractual interpretation issues remained. The agreement specified that all inventions conceived or reduced to practice "at any time during my employment" were assigned to Mattel.123 The sketches and sculpt clearly qualified as "inventions". 124 However, the employment contract did not clarify whether "during my employment" was limited to Bryant's actual working hours or covered the entire period or term of his employment.125 In addition, the employment contract expressly excepted inventions that qualify under the

\footnotetext{
119. Id.

120. Id. (internal quotation marks omitted). Such works could include "know-how" and "discoveries."

121. Id. at 909 .

122. Id. at 910 .

At various stages of litigation, the parties introduced such evidence supporting their respective interpretations of 'inventions.' Contracts Mattel drafted for other employees, for example, expressly assigned their 'ideas" as well as their 'inventions.' This tends to show that the term 'inventions' alone doesn't include ideas. On the other hand, a Mattel executive claimed during her deposition that it was common knowledge in the design industry that terms like 'invention' and 'design' did include employee ideas. Because the district court concluded that the language of the contract was clear, it didn't consider the extrinsic evidence the parties presented. Even if it had, it may not have been able to resolve the meaning of 'inventions.' If the meaning turns in part on the credibility of conflicting extrinsic evidence, a properly instructed jury should have decided the issue.

123. Id. at 909 .

124. Id. at 911.

125. See id. at 913 (holding that summary judgment was inappropriate because there was ample reasoning to read the agreement as covering and not covering non-working hours).
} Id. 
provisions of the California Labor Code section 2870.126 This section limits the extent to which an employer can use an employment agreement to assign inventions that may be outside the scope of employment:

(a) Any provision in an employment agreement which provides that an employee shall assign, or offer to assign, any of his or her rights in an invention to his or her employer shall not apply to an invention that the employee developed entirely on his or her own time without using the employer's equipment, supplies, facilities, or trade secret information except for those inventions that either:

(1) Relate at the time of conception or reduction to practice of the invention to the employer's business, or actual or demonstrably anticipated research or development of the employer; or

(2) Result from any work performed by the employee for the employer. ${ }^{127}$

The two exceptions in section 2870 reasonably approximate the "scope of employment" prong of the work for hire doctrine, as applied to the state law of assignment of employee work product. 128

The Ninth Circuit found that the evidence conflicted as to the interpretation of the phrase "at any time during my employment."129 One Mattel employee testified that "everything I did while at the company belonged to [it]," while another employee testified that "it was common knowledge that a lot of people ... moonlight[ed] ... which wasn't a problem if it was on their own time, and at their own house."130 The Ninth Circuit held that the issue (as to whether Bryant's contract covered his work on Bratz) should have been submitted to the jury under instructions to "determine (1) whether Bryant's

126. Id. at 912 n.5.

127. CAL. LAB. CODE $\S 2870$ (a) (West 2010).

128. Id. The Section concludes by stating, "(b) To the extent a provision in an employment agreement purports to require an employee to assign an invention otherwise excluded from being required to be assigned under subdivision (a), the provision is against the public policy of this state and is unenforceable." Id. Other states with similar statues limiting the scope of employee invention assignment agreements are Delaware (DEL CODE ANN. LABOR 19, § 805 (West 2011)); Illinois (765 ILL. COMP. STAT. ANN. 1060/2 (WEST 2011)); Kansas (KAN. STAT. ANN. § 44-130 (West 2010)); Minnesota (MinN. STAT. ANN. § 181.78 (West 2010)); North Carolina (N. C. GEN. STAT. ANN. § 66-57.1 (West 2010)); Utah (UTAH CODE ANN. § 34-39-3 (West 2010)); and Washington (WASH. REV. CODE ANN. § 49.44.140 (West 2010)), among others.

129. Mattel, 616 F.3d at 912 (internal quotation marks omitted).

130. Id. (internal quotation marks omitted). 
agreement assigned works created outside the scope of his employment at Mattel, and (2) whether Bryant's creation of the Bratz sketches and sculpt was outside the scope of his employment." 131

Mattel also argued that the juxtaposition of the employment agreement and the work for hire doctrine argued in favor of a broad interpretation of the agreement. Under the Copyright Act, employers are the authors of works made for hire under; as such, "the agreement must cover works made outside the scope of employment." 132 If this were not the case employees would be assigning to their employer works, which the employer already owned. 133 The court dismissed this argument on the grounds that the contract provided Mattel additional rights by covering more than just copyrightable works and the contract could "also be enforced in state court, whereas Copyright Act claims must be heard in federal court."134

The portion of Bryant's contract quoted by the Ninth Circuit did not specify Bryant's employment obligations or his duties. Nothing in the facts suggested that Bryant was employed to develop new dolls to compete with or complement Barbie Dolls or other Mattel products. ${ }^{135}$ If Bryant's employment contract had provided that all doll and toy designs were part of his duties for Mattel, then the determination might have been in Mattel's favor. ${ }^{136}$ Likewise, had the

131. Id. at 913. To the extent a contract specifically includes all ideas that are reduced to practice or otherwise fixed during the time of employment, they are within the California Labor Code exception for works that "[r]elate at the time of conception or reduction to practice of the invention to the employer's business, or actual or demonstrably anticipated research or development of the employer."

${ }^{132}$ Id. at 912 n.7.

133. Id.

134. Id.

135. Evidence supports the MGA contention that it investigated the right of Bryant to develop Bratz and concluded the materials were created outside the scope of Bryant's employment at Mattel. See Mattel, Inc. v. MGA Entm't, Inc., No. CV 04-9049, 2010 U.S. Dist. LEXIS 102461, at*13 (C.D. Cal. Sept. 22, 2010) (MGA's attorney emailed Carter's attorney asking "specifically about the Mattel issue and she said she reviewed the chronology of the creation of this design and is satisfied that Carter created it outside the scope of his employment at Mattel.”).

136. The Ninth Circuit states that, on remand, Mattel might well convince a properly instructed jury that Bryant's preliminary Bratz sketches and sculpt were created within the scope of his employment at Mattel. Mattel, Inc. v. 
contract between Mattel and Bryant specified that any new products involving dolls or toys were developed for the benefit of Mattel, then any ambiguity might also have been resolved. ${ }^{137}$

The nature of the Bratz dispute reinforces the need to clarify the scope of an employee's responsibility. In many large corporations however, most employee work for hire invention assignment agreements are standard forms that are not tailored to any particular employee's job duties. ${ }^{138}$ To determine whether an employee's work is produced in the scope of employment, the court may look at the employee's job description. ${ }^{139}$ Such a description can be more influential as to the scope of employment than whether the work was created during working hours or on the employer's premises.

In Marshall v. Miles Laboratories, John Marshall, a staff scientist for Miles Laboratories (Miles), was held to have authored a research paper within the scope of his employment because his job description as "Director of Enzyme Research and Development" was to "develop, summarize and report information about advances in technologies of interest" and maintain an awareness of the latest scientific advances in his specialty. ${ }^{140}$

Marshall claimed that the research paper was not made within the scope of his employment and therefore, Miles did not hold the copyright. Marshall testified that "his contributions to

MGA Entm't, Inc., Nos. 09-5673, 09-55812, 2010 U.S. App. LEXIS 24150, at *19 (9th Cir. Oct. 21, 2010.)

137. On remand, the jury reached a verdict largely favoring MGA. The jury held, among other things, that Mattel did not prove that it owned the name or the concept for the Bratz line of dolls. See Mattel Stole MGA's Bratz Trade Secrets, Jury Says, LAW 360 (April 21, 2011), http://www.law360.com/topnews/articles/240538/mattel-stole-mga-s-bratztrade-secrets-jury-says.

138. See, e.g., Work-For-Hire Agreement, CREATIVE Bus. Solutions, http://www.creativebusiness.com/pdf_free/CBworkforhire.pdf (last visited Apr. 4, 2011).

139. Marshall v. Miles Labs, Inc., 647 F. Supp. 1326, 1330 (N.D. Ind. 1986) (demonstrating a court looking to an employee's job description to determine whether his actions were within the scope of his employment).

140. Id. at 1327, 1330 (citations omitted). Marshall had the following language in his employment contract: "All discoveries or inventions, whether patentable or not, conceived jointly or solely by the EMPLOYEE during the period of employment shall become the property of the COMPANY without additional compensation or consideration." Id. at 1330 n.2. Because the contract was allegedly signed by Marshall under duress, the court did not give it weight when determining the outcome of the case. Id. 
the article were not prepared while he was at his office at Miles, that Miles never specifically instructed him to write the article, and he was never given additional consideration for the article." ${ }^{141}$ The U.S. District Court for the District of Indiana rejected Marshall's assertions, finding:

Neither case law nor the legislative history suggests that a person can avoid the 'work made for hire' doctrine merely by preparing the work during non-working hours or in a facility not controlled by the employer. The mere fact that preparations were done outside an employee's office or normal working hours does not remove such preparations from the scope of employment. ${ }^{142}$

Since the article otherwise qualified as within the scope of Marshall's employment, it was deemed a work for hire of Miles. ${ }^{143}$

In sum, being an employee does not transfer to the employer every copyrighted work developed. Only those works reasonably related to the scope of the employment will vest in the employer. If the copyrighted materials reflect the type of work typical for that employee, then the work for hire doctrine can extend to those works without regard to whether the actual fixation occurred at home or in the office.

\section{SPECIALLY COMMISSIONED WORKS}

The second category of works made for hire applies to specifically commissioned works. For these works, the status of the employee is not relevant. Instead, the work must fall into one of nine categories enumerated under the Copyright Act, and must be transferred to the hiring party in a writing signed by both the person commissioning the work and by the person who prepared the work pursuant to said commission. ${ }^{144}$ If both requirements are met, the copyright vests in the hiring party as the author. ${ }^{145}$

The nine categories of work that are eligible to be specially commissioned works are works used "as a contribution to a collective work, as a part of a motion picture or other audiovisual work, as a translation, as a supplementary work,

141. Id. at 1330 .

142. Id.

143. Id. at 1331; see also 1 DAVID NIMMER, NIMMER ON COPYRIGHT § $5.03[\mathrm{~B}][1][\mathrm{b}][\mathrm{i}](2010)$.

144. 17 U.S.C. $§ 101$ (2006).

145. U.S. COPYRIGHT OFFICE, Works MADE FOR HiRe UNDER THE 1976 COPYRIGHT ACT (2010). 
as a compilation, as an instructional text, as a test, as answer material for a test, or as an atlas." 146

Motion pictures are a prime example, demonstrating the need for extending the work for hire doctrine to specially commissioned works because the screenwriter, director, set designer, cinematographer, and even the actors are not generally employees, but might be contributing copyrighted material to the final product. Motion picture companies typically hire parties using written contracts that specify that the work is done as a specially commissioned work; as a result, the copyright in all elements of the movie vests exclusively in the company. ${ }^{147}$

Similar logistical demands apply to software development and the creation of sophisticated videogames and online content. Software has been argued to be within the nine categories of specially commissioned works either as a part of

146. 17 U.S.C. $§ 101$. To better understand the nine categories of specially commissioned works, the statute definitions provide additional information, for example:

"Audiovisual works" are works that consist of a series of related images which are intrinsically intended to be shown by the use of machines, or devices such as projectors, viewers, or electronic equipment, together with accompanying sounds, if any, regardless of the nature of the material objects, such as films or tapes, in which the works are embodied. ...

A "collective work" is a work, such as a periodical issue, anthology, or encyclopedia, in which a number of contributions, constituting separate and independent works in themselves, are assembled into a collective whole. ...

A "compilation" is a work formed by the collection and assembling of preexisting materials or of data that are selected, coordinated, or arranged in such a way that the resulting work as a whole constitutes an original work of authorship. The term "compilation" includes collective works. . . .

[A] 'supplementary work' is a work prepared for a publication as a secondary adjunct to a work by another author for the purpose of introducing, concluding, illustrating, explaining, revising, commenting upon, or assisting in the use of the other work, such as forewords, afterwords, pictorial illustrations, maps, charts, tables, editorial notes, musical arrangements, answer material for tests, bibliographies, appendixes, and indexes; and an "instructional text" is a literary, pictorial, or graphic work prepared for publication and with Id. the purpose of use in systematic instructional activities. ...

147. See Joseph J. Beard, Clones, Bones and Twilight Zones: Protecting the Digital Personal of the Quick, the Dead and the Imaginary, 16 BERKELEY TECH. L.J. 1165, 1175-77 (2001). 
collective work in the system as a whole ${ }^{148}$ or because the nonliteral elements of the program constitute a compilation. ${ }^{149}$

Not just any writing will qualify as sufficient to make a specially-commissioned work a work for hire. In some decisions, a work for hire agreement providing that a work is a specially commissioned work must expressly include the terms "workfor-hire" or "specially commissioned work."150 Without these express terms, the contract may not be more than an assignment of copyright.151 In other decisions, "talismanic words" are not required so long as the intent of the parties to enter into a work for hire relationship is sufficiently expressed in the written agreement. ${ }^{152}$ Thus, it is always preferable to use these terms if they appropriately express the intent of the parties. Even an assignment of "all right, title and interest" does not intuitively suggest that more than an assignment of the copyright is intended.153 In Numbers Licensing, LLC $v$. bVisual USA, Inc., a copyright notice embedded in the source code that said "Numbers Consulting for bVisual, copyright," was not sufficient to constitute a written agreement that the program was a work for hire. ${ }^{154}$ The Court held this to be inconsistent with Congressional intent to have certainty in copyright ownership at the outset and, further, that the code entries lacked the parties' signatures. ${ }^{155}$

\section{A. LOGICOM INCLUSIVE, INC. V. W.P. STEWART \& CO.}

The case of Logicom Inclusive, Inc. v. W.P. Stewart \& Co. provides a veritable checklist of what to do in the context of specially-commissioned software, namely: (1) make sure that contractors working for another contractor create works for hire for their employer; (2) make sure that a written

148. Numbers Licensing, LLC v. bVisual USA, Inc., 643 F. Supp. 2d 1245, 1253 (E.D. Wash. 2009).

149. Logicom Inclusive v. W.P. Stewart \& Co., 72 U.S.P.Q.2d 1632, 1640 (S.D.N.Y. 2004).

150. Id. at 1641 (citing Armento v. Laser Image, Inc., 950 F. Supp. 719, 730 (W.D.N.C. 1996) ("The Second Circuit has indicated that the omission [of the words 'work for hire'] is fatal.")).

151. Id.

152. Id. at 1641.

153. Playboy Enters., Inc., v. Dumas, 53 F.3d 549, 560 (2d Cir. 1995) ("[assignment] of all right, title and interest" was not sufficient to evidence a work for hire relationship).

154. Numbers, 643 F. Supp. 2 d at 1252.

155. Id. 
instrument mentions "specially-commissioned works" and/or "work for hire;" (3) make sure that the entity claiming to be the author of the copyrighted work is in good standing when the work is created; and (4) a copyright registration only affords a presumption of validity if it is timely filed. ${ }^{156}$

The defendant in Logicom, W.P. Stewart \& Co. (WPS), was a global investment advisor and financial services firm that hired Logicom in 1985 to create software for a number of programs involving the core financial services of WPS. ${ }^{157}$ Logicom created the two copyrighted works at issue in $1995 .{ }^{158}$ Relations deteriorated over attempts to enter into a written agreement and, in early 2003, Logicom's ongoing services were terminated. ${ }^{159}$ WPS continued to modify the software using its own employees and independent contractors. ${ }^{160}$ Logicom sued for copyright infringement for the unauthorized creation of derivative works. ${ }^{161}$

The defense by WPS raised a number of critical points. First, WPS challenged Logicom's ownership of the software created by WPS's own independent contractors. 162 To prevail, the court had to first determine that the software was covered under the statutory definition of a specially commissioned work. ${ }^{163}$ As the Logicom Court recognized, "[c]omputer program" is not expressly listed as one of the nine categories of specially commissioned works under $\S 101$ of the Copyright Act. 164 "However, the case law makes clear that the nonliteral elements of a computer program are properly considered a 'compilation' insofar as the concepts of selection, arrangement and organization, central to the compilation doctrine, are included in the analysis of a computer program's structure." 165 As a result, the creation of software is within the nine

156. See 72 U.S.P.Q.2d 1632, 1632 (S.D.N.Y. 2004).

157. Id. at $1634-35$.

158. Id. at 1635 .

159. Id.

160. Id.at 1636 .

161. Id.

162. Id. at 1639 .

163. Id. at 1640 .

164. Id.

165. Id. (citing Computer Assocs. Int'l, Inc. v. Altai, Inc., 982 F.2d 693, 711-12 (2d Cir. 1992); Harbor Software, Inc. v. Applied Sys., Inc., 925 F. Supp. 1042, 1047 (S.D.N.Y. 1996)). 
enumerated categories of works that may be specially commissioned.

Secondly, for the work to be considered a work for hire, "the parties [must] expressly agree in a written instrument signed by them that the work shall be considered a work made for hire."166 The contract signed by the parties in Logicom stated that "[w]ork [p]roduct created by [c]onsultant . . . shall be the sole property of Company for the sole use of the Company and its clients." 167 Rather than following this narrow interpretation, in Playboy Enterprises Inc. $v$. Dumas, ${ }^{168}$ the judge followed the Ninth Circuit precedent to find the contractual language was sufficient. 169 This was a generous reading in favor of the hiring party, as courts may be reluctant to find work for hire when the plaintiff is an independent contractor claiming not to have agreed to be stripped of statutory copyright protections through vague or ambiguous language. Therefore, although the Logicom court found for WPS, it also serves as a warning regarding the need to use statutory terms in the specially commissioned agreement.

A third warning also flows from Logicom regarding the registration of copyright for startups utilizing software and similar works. A valid copyright registration is a prerequisite to litigation of a copyright infringement claim by a U.S. author. ${ }^{170}$ Without at least an application pending for registration, there can be no copyright action. ${ }^{171}$

The defendant claimed the copyright registration was not valid because the employer firm was not in existence at the time of registration or the filing of the suit. ${ }^{172}$ Logicom had

166. 17 U.S.C. $\S 101(2006)$.

167. Logicom Inclusive, 72 U.S.P.Q.2d at 1641 (5th alteration in original) (citation omitted).

168. 53 F.3d 549, 565 (2d Cir. 1995).

169. Logicom, 72 U.S.P.Q.2d at 1642 (citing Warren v. Fox Family Worldwide, Inc., 328 F.3d 1136, 1141 (9th Cir. 2003) ("[T]here is no requirement, either in the [Copyright] Act or the caselaw, that work-for-hire contracts include any specific wording.")); See generally Playboy, 53 F.3d at $551-65$.

170. 17 U.S.C. $§ 411$ (a) (2006) ("[N]o action for infringement of the copyright in any United States work shall be instituted until preregistration or registration of the copyright claim has been made. ...").

171. If the alleged copyright owner meets the notice, deposit and registration application process, then the suit can proceed even if the copyright office refuses to register the work. See 2 DAVID NIMMER, NIMMER ON COPYRIGHT $§ 7.18$ (2010).

172. Logicom, 72 U.S.P.Q.2d at 1638. 
been lawfully formed in 1990, but allowed its corporate status to lapse in 1994.173 Defendants claimed that "because the corporation had been dissolved, Logicom could not have been the proper 'author' of the two computer programs [written in 1995], as is attested in the certificates of registration [issued in 2002]." 174 In 2003, Logicom annulled the dissolution, returning to good standing as a New York corporation. ${ }^{175}$ The Logicom court relied on the good faith but mistaken belief that a viable corporation existed and the annulment of the dissolutionrather than the formation of another entity-to find the copyright registration was valid. ${ }^{176}$

It is quite common for startup businesses to begin operating before their organizational formalities are completed; even so, the Copyright Act is not generally forgiving to inaccurate registrations. Section 411(b)(b)(1) provides:

A certificate of registration satisfies the requirements of this section and section 412, regardless of whether the certificate contains any inaccurate information, unless-

(A) the inaccurate information was included on the application for copyright registration with knowledge that it was inaccurate; and

(B) the inaccuracy of the information, if known, would have caused the Register of Copyrights to refuse registration. 177

As to prong (A), the applicant's good faith belief that Logicom continued to operate protected the registration. ${ }^{178}$ Nevertheless, Logicom's copyright application should have been invalid under prong (B) because the Copyright Office will typically refuse registration when the application is made by an unauthorized applicant. By accepting the good faith assertion regarding the corporate status, the Logicom court saved the copyright. 179 The inaccuracy caused by registering the copyright in a non-existent corporation was not fatal in this case, but it certainly has the potential to undermine the validity of the registration or the authority of the entity to enter into the work for hire agreement. 180

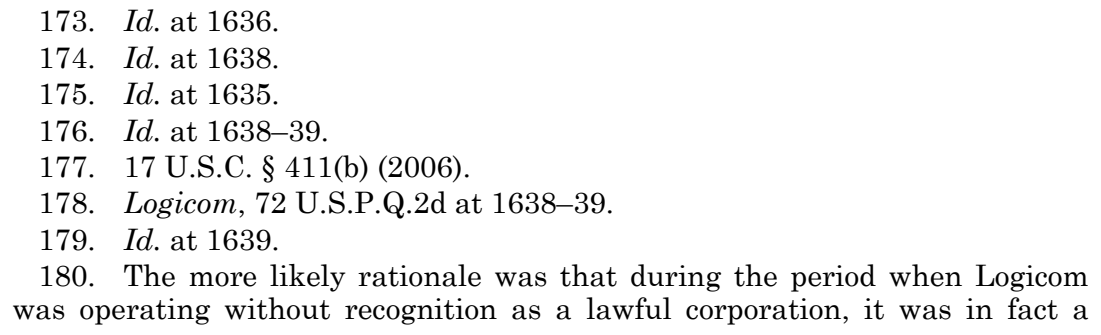

180. The more likely rationale was that during the period when Logicom was operating without recognition as a lawful corporation, it was in fact a 
Finally, the Logicom decision grappled with the validity of the copyright registration itself. The registration was filed December 20, 2002 for a work listed as being created in 1995.181 A copyright registration made before or within five years after the first publication of a work is prima facie evidence of the validity of the copyright and the facts stated in the related Certificate of Registration. ${ }^{182}$ Since the work in this case was a custom software package installed for the benefit of WPS and sold to no other parties, the court correctly determined the software was unpublished. Courts have not provided much guidance regarding the presumption that should be afforded to information contained in copyright registration certificates with respect to unpublished works. Looking to the language of the statute, courts generally find that the copyright is "presumptively valid" by implication because the work is unpublished. 183

The Logicom court relied on a different interpretation of the statute to provide the presumption of validity to the certificate of registration. It held that " $t]$ he statute requires that a court begin its countdown five years after first publication of a copyrightable work." 184 This is an alternative reading of the language "before or within five years after first publication of the work." 185 The Logicom interpretation suggests that the presumption is available only if the work is registered within five years after its publication and essentially ignores the word "before." Factually, the registration for the unpublished work was seven years after its creation, therefore, no presumption of validity was available. ${ }^{186}$ While this is likely the wrong result, a court's interpretation of the Copyright Act

general partnership. As a general partnership, it would have continued to have the authority to enter into the work for hire agreement and register the copyright.

181. Logicom, 72 U.S.P.Q.2d at 1637.

182. 17 U.S.C. $§ 410$ (c).

In any judicial proceedings the certificate of a registration made before or within five years after first publication of the work shall constitute prima facie evidence of the validity of the copyright and of the facts stated in the certificate. The evidentiary weight to be accorded the certificate of a registration made thereafter shall be within the discretion of the court.

$I d$. (emphasis added).

183. See, e.g., Infodek, Inc. v. Meredith-Webb Printing Co., 830 F. Supp. 614, 621 (N.D. Ga. 1993).

184. Logicom, 72 U.S.P.Q.2d at 1638 (emphasis added).

185. See 17 U.S.C. $\$ 410$ (c).

186. Logicom, 72 U.S.P.Q.2d at 1638. 
can sometimes be unpredictable.

What makes this result more understandable in the context of Logicom are the changes that occurred in the computer programs during the seven years between their first creation and their alleged infringement. As testified, the work was subject to "major overhauls." 187 As a result, the registered work may not have borne any reasonable resemblance to the work that was infringed. A registration should be sufficient to protect an infringement of a derivative work, except when only the newly added material is infringed. In those cases, the original registration will not provide a basis for the copyright infringement claim because it does not cover the revisions at issue. ${ }^{188}$

In sum, when addressing the categories of work available for specially-commissioned status, the language in the work for hire agreement, the ownership of copyright by a dissolved corporation, and the effect of delay in obtaining registration, the Logicom dispute provides a roadmap for avoiding the contractual pitfalls of work for hire in the case of specially commissioned works.

\section{NON-APPLICABILITY OF WORK FOR HIRE DOCTRINE}

\section{A. BACK-UP ASSIGNMENT OF COPYRIGHT}

While reliance on the work for hire doctrine is a critical part of planning for United States companies, this doctrine is not recognized in Europe and many other jurisdictions. 189 Moreover, there is ambiguity as to the works that fall within the nine types of works that can be specially-commissioned under the work for hire doctrine, whether the creator is an employee, and whether the work was created in the scope of employment. As a result, companies would be well advised to include saving language in their work for hire agreements, specifying that the copyright in any work that is not recognized under the law as a work for hire is treated by the parties as assigned to the employer. An example of such a saving clause

187. Id. at 1637.

188. See H. Rep. No. 94-1476 (1976).

189. The conflicts of law issues can become quite complex when the employee is located in a foreign jurisdiction that does not recognize the work for hire doctrine. See 1 DAVID NIMMER, NIMMER ON COPYRIGHT, § 5.03[B][1][c] (2010). 
is: "to the extent the work created by contractor/employee in the scope of any [engagement/employment] is not recognized as a work for hire as a matter of law, the contractor/employee hereby assigns any and all copyright in such works to employer." Such an assignment provision will serve to transfer ownership to the employer, "but will not trigger the other legal benefits to the employer that flow from the status of a 'for-hire' work." 190

A written transfer of copyright must meet the requirements of the Copyright Act.191 It must be "an instrument of conveyance, or a note or memorandum of the transfer . . . in writing and signed by the owner of the rights conveyed or such owner's duly authorized agent." 192 "To be valid [as] an assignment under §204(a) [of the Copyright Act, an assignment] must "clearly identify the deal and its basic parameters."' 193 In Playboy Enterprises v. Dumas, the Second Circuit refused to consider as an assignment of copyright a legend on the back of a check on which payee assigned "all right title and interest" in the described painting because it did not mention the word "copyright" and evidence was conflicted as to whether the parties intended to transfer the copyright or only a one-time reproduction right. ${ }^{194}$

Copyright assignment requirements are not satisfied by contracts with third parties. ${ }^{195}$ Recently, in Woods v. Resnick, a court pointed out that it was not sufficient to assign a copyright that Woods, the author of the code, signed (on behalf of F\&I Source) a service agreement with a third party that reserved rights in the code to F\&I Source. ${ }^{196}$ Nor was it sufficient that the terms and conditions on F\&I Source's website, also drafted by Woods, stated that F\&I Source was the sole and exclusive owner of the copyrights on the website. 197 While these were "circumstantial admissions," they did not satisfy the statutory requirements for the assignment of copyright from Woods to

190. Id. $\S 5.03[\mathrm{~B}][1][\mathrm{b}][\mathrm{ii}]$.

191. 17 U.S.C. $§ 204(a)(2006)$.

192. Id.

193. Woods v. Resnick, 725 F. Supp. 2d 809, 826 (W.D. Wis. 2010) (citing Weinstein Co. v. Smokewood Entm't Grp., 664 F. Supp. 2d 332, 342 (S.D.N.Y. 2009)).

194. Playboy Enters., Inc. v. Dumas, 53 F.3d 549, 564 (2d Cir. 1995).

195. See, e.g., Woods, 725 F. Supp. at 826.

196. Id. at 825-26.

197. Id. at 826 . 
F\&I Source. 198 "Instead, the documents confirm[ed] the rights that exist between F\&I Source and third parties." 199 Said the court: "[T] he written documents are not between Woods and F\&I Source and they do not contain any terms clearly identifying the terms of any transfer deal between the two." 200

The purpose of the signed writing requirement is "to ensure that the copyright owner deliberately transfers its ownership interest and that the owner does so in way that provides the parties with a clear guide to their rights and responsibilities." 201 The organizational documents in a limited liability company 202 or a partnership 203 do not necessarily satisfy this obligation. The assignment can be in any agreement signed by the parties, but it must be explicit as to the copyright interests being transferred and not merely implied by the relationship of the parties. ${ }^{204}$

\section{B. JOINT AUTHORSHIP}

Even where work for hire status is applicable to a work, there remains an additional copyright doctrine that can come into play. Rather than characterizing the relationship as employer/employee, a hiring party desiring to retain rights in the copyright might claim the work was jointly authored by the individual author and the hiring party.

A work by more than one author is described by the statute as a "joint work." 205 "A 'joint work' is a work prepared by two or more authors with the intention that their contributions be merged into inseparable or interdependent parts of a unitary whole."206 In a joint work, the co-authors are co-owners of the copyright in the work and hold undivided interests in the work, despite any differences in each other's contribution. ${ }^{207}$ Each

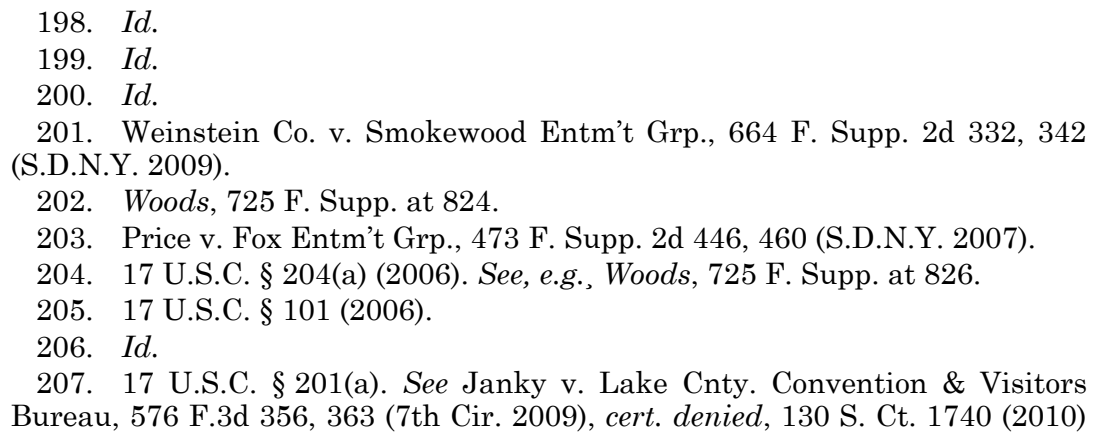


joint author "has the right to use or to license the use of the work, subject to an accounting to the other co-[authors] for any profits." 208 Thus, even a person whose contribution is relatively minor enjoys a significant benefit, so long as he is deemed a joint author. Joint authors receive the benefit of copyright protection for seventy years following the death of the last surviving author. 209

Merely because two people collaborate to create a work does not make them joint authors. ${ }^{210}$ The key to joint authorship is the intent of the authors at the time the work is created to merge their efforts into one work. ${ }^{211}$ The law does not require a signed written agreement to establish joint authorship, although such an agreement would eliminate most related controversies. ${ }^{212}$

In addition, most courts require that each participant contribute copyrightable expressions to the work, not just ideas. ${ }^{213}$ This requires that both authors actually write dialog, narration, music, or, in the case of software, lines of code. Thus, precluding joint authorship where one participant merely provides concepts or suggestions. ${ }^{214}$ Courts have embraced this rule in order to prevent the absurd result that the work was protected by copyright even though each author's contribution was insufficient to be protected alone. ${ }^{215}$ Because the threshold

(holding that a joint work was created where one songwriter contributed only $10 \%$ of the lyrics, but they were significant to the song's commercial viability.)

208. Erickson v. Trinity Theatre, Inc., 13 F.3d 1061, 1068 (7th Cir. 1994).

209. 17 U.S.C. $§ 302(b)$ (2006). If one of the joint authors is an entity, then the copyright term will be based on work for hire measures of 95 years from publication or 120 from creation, whichever is less. Id. $\S 302(\mathrm{c})$.

210. See, e.g., Ashton-Tate Corp. v. Ross, 916 F.2d 516, 521 (9th Cir. 1990).

211. 17 U.S.C. $§ 101$ (2006).

212. For example, a written agreement assigning a treatment for a motion picture defeated a claim that the motion picture itself was a joint work. Richlin v. Metro-Goldwyn-Mayer Pictures, Inc., 531 F.3d 962, 964 (9th Cir. 2008).

213. See, e.g., Ashton-Tate, 916 F.2d at 521.

214. See, e.g., Aalmuhammed v. Lee, 202 F.3d 1227, 1231 (9th Cir. 2000); Thomson v. Larson, 147 F.3d 195, 199-205 (2d Cir. 1998); Erickson v. Trinity Theatre, Inc., 13 F.3d 1061, 1067-72 (7th Cir. 1994).

215. Janky v. Lake Cnty. Convention \& Visitors Bureau, 576 F.3d 356, 361 (7th Cir. 2009), cert. denied, 130 S. Ct. 1740 (2010). But see Gaiman v. McFarlane, 360 F.3d 644, 658-59 (7th Cir. 2004). Here the court did not require each co-author of a comic book character to contribute an independently fixed and copyrightable component because "where two or more people set out to create a character jointly in such mixed media as comic books and motion pictures and succeed in creating a copyrightable character, it 
for copyright protection is rather low, the contribution of expression requirement is usually not too difficult to achieve. 216

With respect to software, in Woods $v$. Resnick, Resnick raised the theory that he and Woods were joint authors of the auto finance program as an alternative to his work for hire claim. ${ }^{217}$ Nevertheless, the fact that Resnick came up with the idea for the dealer finance system and provided directions to Woods regarding what the program should do and how it should do it was not enough to make him a co-author. ${ }^{218}$ As to Resnick's other contributions: (1) there was insufficient proof that he wrote any lines of code; (2) the incorporation of Resnick's finance formulas on excel spreadsheets did not add original copyrightable content, but common ideas; and (3) Resnick's mock-ups of screen displays did not contain independently copyrightable expression as they were nearly identical to other F\&I reports on the market since 1999. 219

Joint authorship is not necessarily desirable as a commercial matter. Either author can independently exploit the work, so that the authors can become competitors, yet neither one can grant exclusive rights to a third party without the participation of the other joint owner. ${ }^{220}$ In addition, the requirement to account for profits has had limited interpretation. ${ }^{221}$ In the entertainment area, the calculation of profits can be quite complex. ${ }^{222}$ Where partners intend to be or are aware that they are joint authors, they often enter into a written agreement waiving the accounting for profits and

would be paradoxical if[,] though the result of their joint labors had more than enough originality and creativity to be copyrightable, no one could claim copyright." Id.

216. Feist Publ'ns, Inc. v. Rural Tel. Serv. Co., 499 U.S. 340, 345 (1991) ("The sine qua non of copyright is originality. .. . To be sure, the requisite level of creativity is extremely low; even a slight amount will suffice.").

217. Woods v. Resnick, 725 F. Supp. 2d 809, 812-13 (W.D. Wis. 2010).

218. Id. at 825 (citing Gaiman, 360 F.3d at 658 ("[P]erson who contributes merely non-expressive elements to a work, such as ideas, suggestions[,] or editorial changes, is not an 'author")).

219. Id. at 819-24.

220. Davis v. Blige, 505 F.3d 90, 100 (2nd Cir. 2007) ([I]n order to convey exclusive rights, all co-owners must agree to convey their shares of the same right).

221. Erickson v. Trinity Theatre, Inc., 13 F.3d 1061, 1068 (7th Cir. 1994).

222. Davis, 505 F.3d at 106 (discussing the difficult process of determining damages relating to copyright infringement in the music industry). 
setting out parameters for licensing their rights.

\section{IMPLIED LICENSE}

If the hiring party fails to prove a work for hire arrangement, an assignment of copyright, or joint authorship, it still has one last arrow in its quiver to obtain rights in the copyrighted work. It can assert that it has an implied license. ${ }^{223}$ Such a license would be non-exclusive because the Copyright Act requires that exclusive licenses, a form of transfer of copyright ownership, be in writing and signed by the owner of the rights conveyed or such owner's duly authorized agent. ${ }^{224}$ Non-exclusive licenses can be granted orally or by implication. ${ }^{225}$ Where consideration has been paid for the creation of the work, the license may be found to be irrevocable. ${ }^{226}$

Finding an implied license is not automatic. It requires a determination that " 1 ) a person (the licensee) request[ed] the creation of a work, 2) the creator (the licensor) ma[de] that particular work and deliver[ed] it to the licensee who requested it, and 3)the licensor intend[ed] that the licensee-requestor copy and distribute his work." 227 The intent requirement is itself broken out into a three-prong test, i.e., "(1) whether the parties were engaged in a short-term discrete transaction as opposed to an ongoing relationship; (2) whether the creator utilized written contracts . . . providing that copyrighted materials could only be used with the creator's future involvement or express permission; and (3) whether the creator's conduct during the creation or delivery of the copyrighted material indicated that use of the material without the creator's involvement or consent was permissible." 228

In Numbers Licensing, LLC $v$. bVisual USA, Inc., a software development company argued for an implied license

223. Asset Mktg. Sys., Inc. v. Gagnon, 542 F.3d. 748, 754-55 (9th Cir. 2008).

224. See 17 U.S.C. § 101 (2006) (defining "Transfer of Copyright Ownership" to include an "exclusive license"); 17 U.S.C. $§ 204$ (a) (2006) (requirements for transfer of copyright ownership include a signed writing).

225. Asset, 542 F.3d at 754 .

226. Id. at 757 ; see also 3 DAVID NIMMER, NIMMER ON COPYRIGHT $\S$ $10.02[\mathrm{~B}][5](2010)$.

227. Numbers Licensing LLC v. bVisual USA, Inc., 643 F. Supp. 2d 1245, 1252 (E.D. Wash. 2009) (citing Asset, 542 F.3d at 754-55).

228. Asset., 542 F.3d at 756 (citing Danielson v. Winchester-Conant, 322 F.3d 26, 41 (1st Cir. 2003)). 
[Vol. 12:2

after it failed to establish that a program created by Rand Renfroe through his personal corporation, Numbers, was a work for hire.229 The court held that bVisual obtained an implied license to continue using the system's source code. 230 The parties' failure to have a written agreement contradicting a license, the fact that Numbers did not, despite numerous opportunities, deny a license until the relationship ended, that Numbers inserted a copyright notice in the code that said "Numbers Consulting for bVisual, copyright," and that Numbers was paid a substantial sum in both money and stock for the delivery of the code all played into the court's decision. ${ }^{231}$ The court summed it up thusly, "When a license has not been denied and substantial sums of money are paid for the copyrighted work, the absence of a licensing agreement supports the finding of an implied license." 232

Where the facts establishing work for hire and joint work are controversial and, therefore, not susceptible to resolution on a preliminary motion, an implied license provides the aggrieved party continued access to the software, pending final resolution of the other claims. Credit Bureau Connection Inc. $v$. Pardini presents such a case. ${ }^{233}$ In Pardini, the parties were equal stockholders of Credit Bureau Connection (CBC), a joint venture company undertaking the development and marketing of finance and insurance software for automobile dealerships. ${ }^{234}$ One stockholder asserted that CBC owned the program as a work for hire because, among other things, CBC reimbursed the cost of the programming supervisor and his assistants and supplied office space and some of the development tools. ${ }^{235}$ The other stockholder, Data Consultants, argued that the programmers were its own employees and received employment benefits directly from Data Consultants. ${ }^{236}$

The District Court for the Central District of California

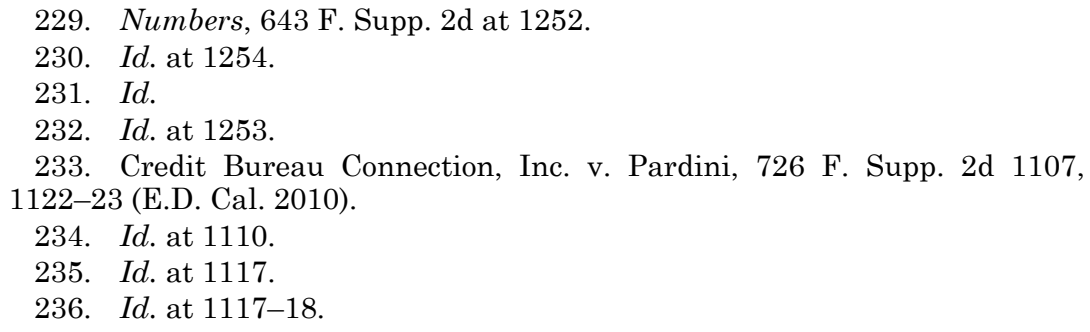


held that CBC did not carry its burden to prove that the programmers were employees of $\mathrm{CBC}$ or that the programming supervisor and CBC made a jointly-authored work. ${ }^{237}$ However, CBC was successful in establishing that it had an implied license. ${ }^{238}$ The software was delivered to $\mathrm{CBC}$ for its use; and, for nearly three years, CBC marketed the program under its own name with unlimited use and access thereto, working with the programmers to modify it throughout that time period. ${ }^{239}$

The terms of an implied license to software, such as whether the license includes the source code, the right to modify it, and even the duration of the license, may be contested. In Pardini, the license was found to include the right to modify the code, was not limited to existing customers, and, because the hiring party paid money towards the creation of the software, the license was irrevocable. ${ }^{240}$ In Asset Marketing Systems, Inc. v. Gagnon, the Ninth Circuit found that the implied license included the source code because the author delivered it to Asset Marketing Systems (AMS), the hiring party, by installing and storing it on AMS's computer. ${ }^{241}$ The court also found support for AMS's right to modify the code by reference to the parties' Technical Services Agreement (TSA). ${ }^{242}$ The TSA stated that Gagnon, the programmer, would provide "specific add-on products" for an hourly fee, but did not restrict AMS's own ability to modify the program. ${ }^{243}$ Finally:

[I]t defies logic that AMS would have paid Gagnon for his programming services if AMS could not have used the programs without further payment pursuant to a separate licensing arrangement that was never mentioned in the TSA, and never otherwise requested at the time. ... [C] ustom software is far less valuable without the ability to modify it. ${ }^{244}$

\section{CONCLUSION}

Most business works are created as works made for hire, which vests the copyright in the employer rather than the

237. Id.

238. Id. at $1119-20$.

239. Id. at 1120,1126 .

240. Id. at 1120 (citing Asset Mktg. Sys., Inc. v. Gagnon, 542 F.3d. 748, 757 (9th Cir. 2008) ("a "nonexclusive license supported by consideration is a contract' and is irrevocable")).

241. Asset, 542 F.3d at 755 .

242. Id. at 756 .

243. Id. at 756-57.

244. Id. at 757 . 
[Vol. 12:2

employee. The employment relationship will generally depend on an existing common law agency relationship between the parties. If an employer-employee relationship cannot be established, then the work for hire doctrine may still have a role for works that fall into enumerated categories, as long as a proper written agreement is executed by both parties.

If there is no employment relationship, the work does not fall into one of the nine statutory categories of speciallycommissioned works, and/or there is no adequate written agreement characterizing such work as a work for hire or otherwise assigning it to the hiring party, then a joint authorship may be found. This generally requires that the parties share in the creation of the copyrighted aspects of the work. If a joint authorship cannot be established, then the hiring party may still be able to claim an implied non-exclusive license to use the work.

Establishing a work for hire by an employee in the scope of employment, joint authorship, or an implied license does require not a written agreement. Because the record may be problematic, a written understanding of the relationship between the parties is useful to resolve most copyright ownership claims.

The characterization of a copyrighted work as a work for hire, a joint work, an assignment, or a license affects not only ownership but also is important to properly characterize ownership, length of the copyright term, moral rights, exclusive usage, and termination rights. The cases and examples provided in this article should help a company navigate the landscape of copyright ownership in the ever-changing world of cyberspace. 